\title{
The context of Early Medieval barrows in western Europe
}

\author{
ROBERT VAN DE NOORT*
}

In the early Middle Ages there was a short period when prehistoric burial mounds were reused and new barrows constructed over much of western Europe. This is interpreted as an expression of opposition to the new Christian ideology, in a time of social changes in the distribution of power and property.

In his article 'Time regained: the creation of continuity', Richard Bradley, reassessing monuments at Yeavering, Sutton Hoo, the Boyne tombs and other sites in Britain and Ireland, concludes that in the early Middle Ages '. . . the past was being used in a more active manner, in order to promote the interests of a social elite' (1987: 14-15). The present article elaborates on this theme of active use of the past and prehistoric monuments in the early Middle Ages. It investigates a relative short period in the early Middle Ages, wherein prehistoric burial mounds were reused and new barrows were constructed in England and on the Continent. It will be argued that this funerary practice was a response to the church-graves which had created an opportunity for elaborate and longstanding monuments for the deceased. Not only were barrows a monumental answer to the church-graves but, because of their association with prehistory, burial mounds also expressed the opposition of non-Christians to the Christian élite.

Synthetic approaches to early Medieval barrows have been presented before, most notably Ament (1975) and Shephard (1980). Significantly, neither of these crosses the Channel. The force of this paper lies in studying the early Medieval barrows on the Continent and in England as a single phenomenon and consequently I have drawn heavily from these publications, as well as Meaney (1964).

Many of the barrows, of prehistoric, Roman and Medieval date, were excavated in the 19th and early 20th centuries (FIGURE 1) One of the great barrow diggers of that time was Mortimer (1905). As a consequence of these early activities, it is not always possible to find accounts of the antiquarian studies and the dating of the finds is often unjustified and unreliable. Several hundred burial mounds were built in the Middle Ages, but only a minority has been securely dated, which will be reflected in the distribution map presented here.

Although the setting of the barrows is not discussed here, recent excavations often reveal that barrows were part of larger cemeteries: e.g. Basel Bernerring (Moosbrugger-Leu 1982), Dittigheim in Alamannic Baden Württemberg (Stork 1985), Moos-Burgstall in Niederbayern (von Freeden \& Köhler 1981; von Freeden 1987) and Spong Hill in East Anglia (Hills 1977; 1980). In the past, the archaeological context of burial mounds has often been misinterpreted. At Sutton Hoo, for example, recent re-excavations revealed a much greater prehistoric use of the cemetery than was previously known (Carver 1989). Detailed discussion of early Medieval burial mounds is severely limited by the quality of archaeological research in the 19th and early 20th centuries ( $c f$. Shephard 1979: 49).

On the Continent, recent research has added many new sites of early Medieval burial mounds to the published list of Ament (1975). In England, new additions to Meaney's Gazetteer (1964) are relatively scarce. It seems reasonable to suggest, therefore, that the recovery of barrows in England has been much greater in the past than on the Continent.

* 66 Brincliffe Edge Road, Sheffield S11 9Bw, UK.

AN'TIQUITY 67 (1993): 66-73 


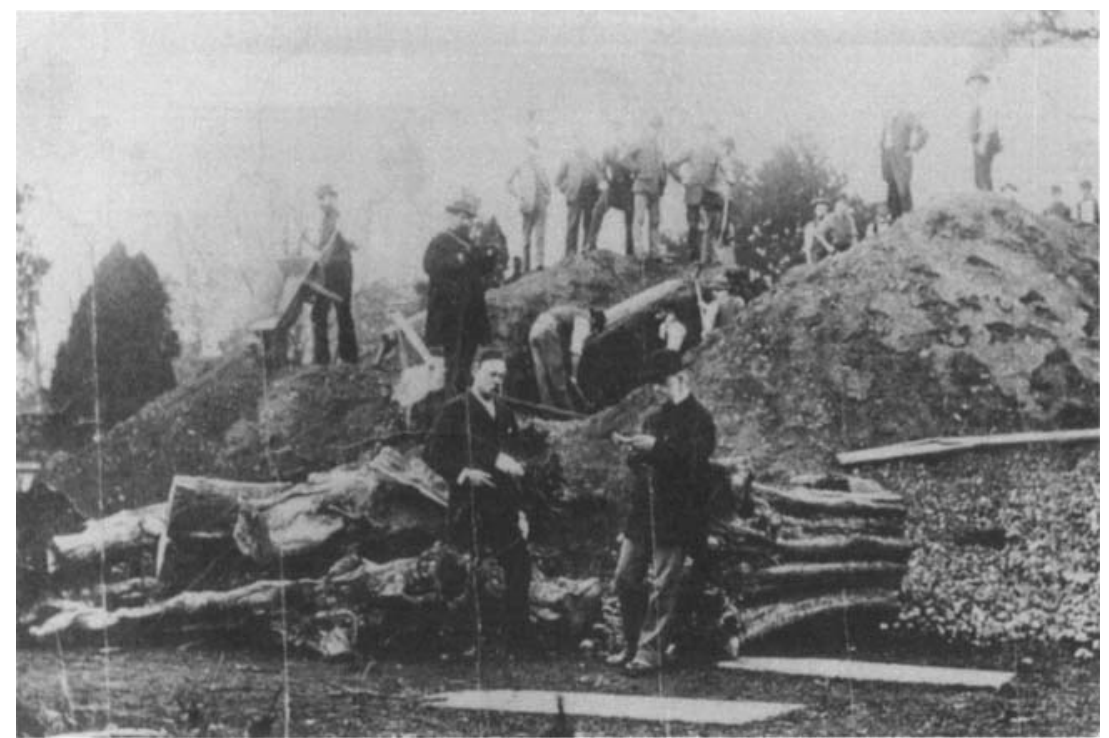

FIGURE 1. The excavation of the burial mound in the churchyard of Taplow, Buckinghamshire, in 1882 .

\section{An overview}

In the distribution of all Early Medieval (AD 450-1000) barrows, three regions stand out: Scandinavia, England and western Germany plus northern Switzerland, especially the area along the Rhine and the upper Danube. The burial mounds of Scandinavia can be considered as a separate tradition from western Europe on the basis of early origin and likely continuity. This burial custom in Scandinavia goes back to at least the later Roman Iron Age with huge mounds at Högom in Norrland, continuing in Uppland and Bertnem and ending in the Vestvöld and in Jutland in the 10th century (Ramqvist \& Müller-Wille 1988). There was a certain amount of mutual inspiration in aspects of funerary behaviour between Scandinavia on the one hand and England and the Rhine/upper Danube area on the other. The boat burials covered by mounds (Müller-Wille 1968/9) and the presence of Frankish weapons in the barrow graves in Högom and Uppland (Ramqvist \& MüllerWille 1988) are examples of this connection.

However, with only a few exceptions, the construction of burial mounds in England and the Rhine/upper Danube area was limited to the period 550-750 (FIGURE 2). This tradition was very similar in both regions, but contrasts sharply with its Scandinavian counterpart. Secondary interments in Neolithic, Bronze and Iron Age barrows were common in all western European areas where burial mounds were built, but not in Scandinavia. There, burial mounds were grouped into barrow cemeteries. In western Europe, isolated mounds, barrow cemeteries and burial mounds within predominantly flat-grave cemeteries have been excavated. Ring ditches around graves have been linked with barrow building. Shephard (1979: 47-8) has suggested that ring ditches in flat-grave cemeteries preceded the mounds as an early type of monumentalized grave, but in recent excavations, such as at Finglesham in Kent, ring ditches are also associated with later, 7 th-century graves (Campbell et al. 1982: 24-5). Again, only in the western European areas, but not in Scandinavia, have unmounded ring ditches been located.

In western Europe, most of the barrows built before 550 and after 750 clearly do not belong to the same tradition as the mounds from the period 550-750, with the exception of Saxony, where barrows were constructed throughout the 7 th and 8 th centuries. Several of the barrows dated before 550 are located in southwest France. Ten of these have been identified by James (1977) who dated them to the late Roman or early Merovingian period. He stresses the point that seven out of ten mounds are located in the Massif Central, an area 'which was probably never more that superficially Romanized' and 'seems to have preserved customs of burial which go right back to the pre-Roman period' (James 1977: 


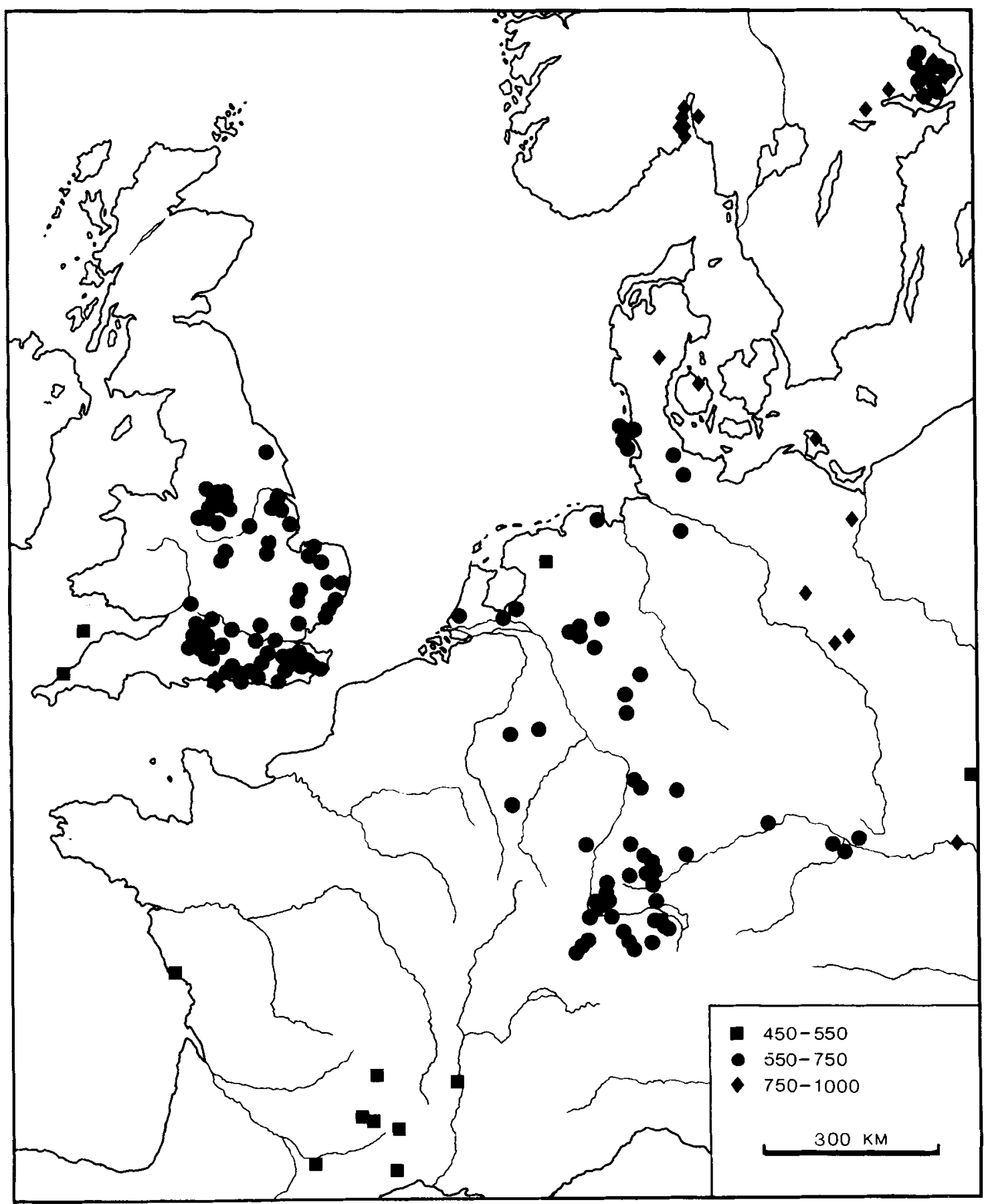

FIGURE 2. Distribution of dated burial mounds and barrow cemeteries (including some graves with ring ditches, thought to have been mound graves). 
182). Another group of burial mounds dated to the 5 th and early 6 th centuries has been identified in western Britain and Scotland. Recent excavations of a part of the cemetery at Tintagel in Cornwall found evidence for an early 6th-century date for Mound C (Morris et al. 1990). This and other barrows (at Hayle in west Cornwall and on Lundy in the Bristol Channel; $c f$. Morris et al. 1990) are described as 'a distinctive sub-class of the wider "special grave” phenomenon' which 'reflect an imitation of Christian funerary practice in 5 thcentury Gaul if not also further afield' (Morris et al. 1990: 848).

In Wales and Scotland, recent excavations have also indicated the use of barrows and ditches around graves in the early Medieval period. At Tadderwen, Clwyd, in Wales, a small cemetery was excavated near a Bronze Age barrow. The cemetery included several 'square-ditched graves' and the large Bronze Age burial mound was surrounded by a square ditch with centrally-placed gaps on all sides, which may be the result of an attempt to incorporate the barrow in the cemetery. A single radiocarbon sample dated the cemetery to 433-680 (James 1992: 92-3). Squareditched graves, together with ring-ditches, are also known from Pictland in Scotland (Alcock 1992: 127-8). It has been suggested that the square-ditched graves from Tadderwen and Pictland may belong to the same tradition and the striking similarities with the late Iron Age Arras group in East Yorkshire are stressed (James 1992: 93).

Barrow cemeteries dating to the later 8th, 9th and 10th centuries have been found east of the river Elbe. Examples are the 700 mounds excavated in two cemeteries in and near the trade settlement Ralswiek on Rügen island in the Baltic. The settlement was occupied between the 8 th and the 13th centuries and is described as a Slavic emporium. The mounds were small (1-2 $\mathrm{m}$ in diameter) and no flat graves have been found in these cemeteries (Donat \& Heydick 1989: 588-91). Isolated burials in mounds from this period are known sporadically from northern England: for example the 9th- or 10th-century finds from the Bronze Age barrow of Lilla Howe, on the North York moors (Watkin \& Mann 1981).

The mounds constructed before 550 in western Europe have been associated with
Romanized groups or with pre-Roman traditions. Those built after 750 in Slav areas constitute a separate tradition. The barrows dated between 550 and 750 , on the other hand, are located in areas within western Europe where Germanic people were politically and militarily dominant in previously Romanized lands: the Alamanns in the upper Rhine area, the Bavarians in the upper Danube area, Austrasian or Rhine Franks in the middle Rhine area, Saxons in northern Germany, Saxons and Jutes in southern England and Angles in East Anglia and the Midlands. Significantly, burial mounds from this period in the core of the Merovingian empire are not known.

The origin of the tradition is not completely clear. It may have been imported in east England by the Angles, Jutes or Saxons, either copying Scandinavian funerary behaviour or continuing indigenous practices. However, isolated examples of Germanic burial mounds are also known from other areas (the burial mound at Zuran near Brünn, dated to c. 500 and possibly commemorating a Lombard king, for example). With so many prehistoric burial mounds visible, it is possible that the adaptation of the barrow in funerary practices originated more or less at the same time in several areas in the early Middle Ages. The re-use of prehistoric barrows, common in England and on the Continent no later than the 6th century, had possibly created precedents in early Medieval burial mound construction.

Attempts to distinguish an early and a late phase in mound construction between AD 550 and 750 leads to a considerably reduced data set. However, it seems that a spatial shift occurred between an early and a late phase. On the Continent in the early phase (550-675; including Böhner's Stufe V, which has been used in most publications) barrow burials were restricted to the Rhine basin and to northern Switzerland. In the later phase (675-750) barrow burials were distributed to the east of the Rhine and within the area of the upper Danube (see also Stein 1967: 121). In England, a spatial shift between an early and a late phase is less well recognizable, but it seems that in the early phase, before $c$. AD 650 , burial mounds were distributed to the east of a line from the Humber and the Trent to the Isle of Wight. In the late phase (650-750) burial mounds were also construct- 
ed west of this line. It should be stressed, however, that only a minority of the English barrows can be securely dated.

\section{Pagan or Christian?}

Charlemagne outlawed burial near or underneath burial mounds in his Capitulatio de partibus Saxoniae in the late 8th century, as it was then considered a pagan practice (Roth 1984: 28; Stein 1967: 206). By this time, barrows were no longer constructed in the Rhine and upper Danube areas and his legislation was directed against the Saxons and the Slavic areas to the east ( $c f$. Ament 1975: 90-93). However, several authors have reasoned that the barrows in the preceding centuries had a pagan connotation as well (Ament 1975: 90-93).

A closer look at the grave goods from mound burials reveals a few finds with explicit Christian symbolism. Examples are the gold-leaf cross in the barrow at Oberiflingen, in Alamannia (Ament 1975: 71), the sarcophagus of stone decorated with crosses on top of one of the mounds at Dondelange in Luxemburg (Ament 1975: 91), the cross on the Benty Grange helmet (Ozanne 1962-3) and the much-discussed Christian grave goods from Sutton Hoo, most notably the baptismal spoons (Bruce-Mittford 1983). In all these instances, however, grave goods with a non-Christian connotation were found as well: the spear in Oberiflingen, a complete weapon set at Dondelange, the boar on top of the Benty Grange helmet and the boat, helmet, weapons and other ostentatious grave goods from Sutton Hoo. These weapons can be understood as part of the 'warrior ideology' of the Germans prior to their conversion (Härke 1990), and the Benty Grange helmet contains powerful symbols of both paganism and Christianity (Evans 1991: 59-60).

The neat division between 'Christian' and 'pagan' in funerary practices was in large measure created by Christians (Markus 1990: 28). For most pagan Germans, Christianity meant initially a new dimension to their existing beliefs. The gold-leaf cross of Oberiflingen and the cross on the Benty Grange helmet indicate that the bearers had either added the Christian God to their pantheon or that the cross as a symbol was not linked to Christianity but, for example, to the élite in the Merovingian empire or Kent respectively.
Discussions on the religion of the person buried in the Sutton Hoo boat burial have usually resulted in similar conclusions ( $c f$. Parker Pearson et al. in press).

The vast majority of mound burials have no grave goods which may link them to Christian beliefs. Rather, they are often furnished with weapons. More importantly, many Germanic cemeteries are located near or around prehistoric mounds and Roman tumuli, suggesting that barrows of earlier date were recognized and had an explicit meaning within the preChristian ideology ( $c f$. Dickinson 1983: 248). Merdingen in Südbaden (Fingerlin 1971) and Wigber Low in the Peak District (Collis 1983) are just two out of numerous examples of the re-use of prehistoric burial mounds. In contrast, early Medieval cemeteries of Christians in Gaul were often located near Roman cemeteries where the bodies of saints and martyrs were buried (Young 1975). In Christian Wales, continuous use of the Roman cemetery of the civitates of Caerwent from the 4 th to the 11th centuries has also been demonstrated (James 1992: 96).

\section{Status and wealth}

It can be argued that burial mounds indicate a relatively high status of the deceased thus commemorated. This could be argued from the relative energy expended on mound construction in contrast to the digging of flat graves ( $c f$. Tainter 1975). Associated grave goods from barrow graves can, in several instances, be ascribed to high-status groups. Examples of these rich finds are known from Biberist in Switzerland (Ament 1975: 66) Oberiflingen in Germany, Dondelange in Luxemburg (Ament 1975: 71) and Taplow and Sutton Hoo in England (Meaney 1964). The notion of Medieval barrow burials as 'special' or high-status rites has been expressed before by many, including Ament (1975), Arnold (1980: 135), Moosbrugger-Leu \& Keller (1979: 62), Müller-Wille (1982) and Shephard (1979). Corroborating the energy expenditure hypothesis, secondary burials of early Medieval date in prehistoric barrows generally do not include high-prestige goods, but notable exceptions exist (e.g. Swallowcliffe Down: Speake 1989). Conversely, rich grave goods in mound graves are nearly always found in purpose-built barrows.

However, the barrow graves displaying 
extremely wealthy goods, fit for a king or a member of the upper nobility, make up only a fraction of the total number of mound burials. Three alternative burial rites were open to élite groups in western Europe between $\mathrm{AD}$ 550 and 750: burials inside churches, separate élite cemeteries and rich graves without mounds or ring ditches within the perimeter of the main cemetery.

The concept of burial inside a church, an existing Mediterranean practice, is generally believed to have been initiated in western Europe for the burial of the Merovingian king Clovis, who died in 511 ( $c f$. Périn 1987). Thereafter, churches were used for graves throughout the Merovingian realm in the 6th century. In England, there are burials in churches dated to the 7 th century. Burials inside churches in western Europe were, in the 6 th and 7 th centuries, restricted to kings (or parts of their bodies), close relatives and the upper nobility, saints and clergy (Périn 1987: 354-60). In the 8th century and after, lesser élite groups similarly used churches for this purpose .

In the centre of the Merovingian empire, church burials were proper ad sanctos burials, with graves close to relics. Further away from Paris, church burials were often a mix of Christian and pre-Christian ideas (the furnished grave of the boy in Cologne Cathedral, for example: Doppelfeld \& Weyers 1980) or were not linked to relics. Church founders' graves (with the founder's grave an integral part of the original church, the so-called Arkosolgräber: Treune Grosskopf 1989) and churches built over existing pagan élite cemeteries are other examples of the mixture of Christian and non-Christian aspects of funerary behaviour.

Separate élite cemeteries came into fashion in the 7 th century, especially but not exclusively in the upper Rhine/upper Danube area. Most of these cemeteries originated in the 7 th century and several had churches built over them during the 8th century (Steuer 1989). In England, separate élite cemeteries other than barrow cemeteries are not known.

Rich graves without a barrow or ring ditch but within larger cemeteries are well known from the later 5th, 6th and early 7 th centuries throughout western Europe (e.g. at Flonheim and graves 1782 and 2268 at Krefeld-Gellup), but became increasingly rare in the later 7 th and 8th centuries. Stein, in her compendium of 8th-century graves of the nobility in Germany (1967) included a significant number of rich graves in larger cemeteries. Later criticism of her work, especially by Last \& Steuer (1969), Hinz (1970) and Steuer (1989), however, pointed out that the vast majority of these graves should be ascribed to local élites, such as rich farmers and freeman. A similar development is visible in England, although the wealth of the richest graves (e.g. Broomfield) scarcely matched its European counterparts.

In only a few instances of mound burial (most notably at Sutton Hoo, Taplow and Oberiflingen) would the owners have belonged to the upper nobility and been able to consider the alternative of a church grave. The preference for a barrow burial may in these instances have been religiously inspired. In most cases, however, burials underneath mounds were carried out not by the upper nobility but by members of local élites. On the Continent, their choice was either a separate élite cemetery or a burial mound. In England, the local élites expressed a clear preference for barrows, either isolated or in groups (Shephard 1979: 48, 50).

\section{Conclusions}

Funerary practices in general maintain existing social structures through the use of religious or ideological concepts (Huntington \& Metcalf 1979; Parker Pearson 1982). The graves of Germanic peoples, furnished with weapons, reflect their warrior ideology. Within that specific ideological concept, the wealth of the grave goods may indicate the status of the mourners, rather than the warring exploits of the deceased (Härke 1990). Graves inside churches and in close proximity to relics indicate prestige and status within the Christian religion. But churches themselves were, to Germanic eyes, a grandiose innovation of the funerary rite. Moreover, such graves were monuments, to be admired by the generations that followed.

When the use of churches as burial locations spread throughout western Europe from the centre of the Merovingian world, the concept of barrow construction, as a monumentalized funerary practice, also became more widespread on its peripheries and beyond. The southeast of England may be considered 
as on the periphery or just beyond the Merovingian empire (cf. Wood 1983). These diffusive developments on a European level would explain the differences in burial mound distributions between the early and the late phases, as described above. Intriguingly, on a regional level, the richest mound graves were built when church graves were constructed nearby (especially in northern Switzerland, but also in England, e.g. Taplow barrow and the church at Dorchester on Thames).

The concern with monumental graves may have been linked to social changes in the distribution of power and property. Steuer (1989: 111-13), for example, has argued that landed property was of ever-growing importance in the later 6th and 7 th centuries. Church graves and burial mounds would have created a clear link between the successors of the deceased and their land ( $c f$. Chapman 1980: 66-7), as ties to the ancestors were made visible.

However, burial mounds primarily expressed opposition to the new Christian

\section{References}

ALCOCK, E. 1992. Burials and cemeteries in Scotland, in Edwards \& Lane (ed.): 125-9.

AMENT, H. 1975. Merowingische Grabhügel, in W. Schlesinger (ed.), Althessen im Frankenreich: 63-93. Sigmaringen: Nationes 2.

ARNOLD, C. 1980. Wealth and social structure: a matter of life and death, in Rahtz et al. (ed.): 81-142.

BRADLEY, R. 1987. Time regained: the creation of continuity, Journal of the British Archaeological Association 140: 1-17.

BRuCE-MITFORD, R. 1983. The Sutton Hoo Ship burial 3. London: British Museum.

CAMPBEll, J., E. JOHN \& P. WORMALD. 1982. The Anglo-Saxons. London: Phaidon.

CARvER, M.O.H. 1989. Anglo-Saxon discoveries at Sutton Hoo, 1987-88, Old English Newsletter 22: 33-7.

CHAPMAN, B. 1980. Death, culture and society: a prehistorian's perspective, in Rahtz et al. (od.): 59-79.

Collis, J. 1983. Wigber Low, Derbyshire. A Bronze age and Anglian burial site in the White Peak. Sheffield: Department of Archaeology and Prehistory, University of Sheffield.

DiCkINSON, T.M. 1973. Excavations at Standlake Down in 1954: the Anglo-Saxon graves, Oxoniensia 38: 239-57.

DONAT, U. \& E. HEYDICK (ed.). 1989. Archäologie in ideology of the Frankish empire ( $c f$. Moreland \& Van de Noort 1992). The top-ranking élite was drawn in this ideology, as expressed in the widespread use of church graves throughout the empire, but local élites were left outside the inner circle.

Monumentalization in the form of the burial mound can not be considered to be arbitrary. Through their link with the prehistoric era, the construction of Medieval burial mounds articulated the opposition of pagans to a changing ideological world and promoted their own interests by actively using the past. In Bradley's words, the pagans created continuity with the pre-Roman past by (re-)inventing the tradition of barrow construction ( $c f$. 1989: 2-5). Thereby, a pan-European mortuary innovation appeared at the peripheries and outside the Christian world.

Acknowledgements. Thanks are due to Tania Dickinson, Alex Woolf, John Moreland, Jane Cartledge, Mike Parker Pearson and the anonymous referees who read and commented on earlier versions of this article.

der deutschen demokratischen Republik, Denkmale und Funde 2: Fundorte und Funde. Leipzig: Akademie Verlag.

DOPPELIELD, O. \& W. WeYRES. (ed.). 1980. Die Ausgrabungen im Dom zu KöIn. Mainz: Von Zabern.

EDWARDS, N. \& A. LANE (ed.). 1992. The early church in Wales and the west: recent work in Early Christian archaeology, history and placenames: 125-9. Oxford: Oxbow. Monograph 16.

FINGERLIN, G. 1971. Die alamannischen Gräberfelder von Güttingen und Merdingen in Südbaden. Berlin: Germanische Denkmäler der Völkerwanderungszeit. Serie A, Band 12.

HÄRKE, H. 1990. 'Warrior graves'? The background of the Anglo-saxon burial rite, Past and Present 126: $22-43$.

HILLS, C. 1977. Chamber graves from Spong Hill, North Elham, Norfolk, Medieval Archaeology 21: $167-76$

1980. Anglo-Saxon cremation cemeteries with particular reference to Spong Hill, Norfolk, in P. Rahtz, T. Dickinson \& L. Watts (ed.), AngloSaxon cemeteries 1979. The Fourth AngloSaxon symposium at Oxford: 197-207. Oxford: British Archaeological Reports. British series 82.

HINZ, H. 1970. Zu den 'Adelsgräber' des 8. Jahrhunderts, Offa 27: 31-55.

Huntington, R. \& P. MEtCAlf. 1979. Celebrations 
of death; the anthropology of mortuary ritual. Cambridge: Cambridge University Press.

JAMES, E. 1977. The Merovingian archaeology of south-west Gaul. Oxford: British Archaeological Reports. Supplementary series 25 (i \& ii).

JAMES, H. 1992. Early medieval cemeteries in Wales, in Edwards \& Lane (ed.): 90-103.

LAST, M. \& H. STEUER. 1969. Zur Interpretation der beigabenführenden Gräber des achten Jahrhunderts im Gebiet rechts des Rheins, Nachrichten aus Niedersachsens Urgeschichte 38: 25-88.

MARKUS, R. 1990. The end of ancient Christianity. Cambridge: Cambridge University Press.

MEANEY, A. 1964. A gazetteer of early Anglo-Saxon burial sites, London: Allen \& Unwin.

MoOsBrugger-Leu, R. 1982. Die frühmittelalterlichen Gräberfelder von Basel. Basel: Christoph Merian Verlag.

MoOSBRUGGer-LEU, R. \& H. Keller. 1979. Der Adel, Ur- und Frühgeschichtliche Archäologie der Swei, Band IV: das Mittelalter: 53-74. Basel: Separatum.

MORELAND, J. \& R. VAN DE NOORT. 1992. Integration and social reproduction in the Carolingian empire, World Archaeology 23: 320-34.

MORRIS, C.D., J. NOWAKOWSKI \& C. THOMAS. 1990. Tintagel, Cornwall: the 1990 excavations, Antiquity 64: 843-9.

MORTIMER, J.R. 1905. Forty years' researches in British and Saxon burial mounds in East Yorkshire. London: A. Brown \& Sons.

MÜLLER-WILLE, M. 1968/9. Bestattung im Boot. Studien zu einer nordeuropäischen Grabsitte, Offa 25/26.

1982. Königsgrab und Königsgrabkirche. Funde und Befunde in frühgeschichtlichen und mittelalterlichen Nordeuropa, Bericht der RömischGermanischen Kommission 63: 349-412.

PARKER PEARSON, M. 1982. Mortuary practices, society and ideology: an ethnoarchaeological study, in I. Hodder (ed.), Symbolic and structural archaeology: 99-113. Cambridge: Cambridge University Press.

PARKER PEARSON, M., R. VAN DE NOORT \& A. WOOLF. In press. Three men and a boat; Sutton Hoo and the Saxon kingdom, Anglo-Saxon England 22.

PÉRIN, P. 1987. Des nécropoles romaines tardives aux nécropoles du Haut-Moyen Age. Remarques sur la topographie funéraire en Gaul mérovingienne et à sa périphérie, Cahiers Archéologiques 35: 9-30.

RAHTZ, P., T. DICKINSON \& L. WATTS (ed.). 1980. Anglo-Saxon cemeteries 1979. The fourth AngloSaxon symposium at Oxford: 81-142. Oxford British Archaeological Reports. British series 82.

RANQVIST, P.H. \& M. MÜLLER-WILlE. 1988. Regionale und überregionale Bedeutung des völkerwanderungszeitlichen Gräberfeldes von Högom, Medelpad, Nordschweden, Germania 66: $95-134$.

ROTH, H. 1984. Frühmittelalter-Archäologie, in H. Roth \& E. Wamers (ed.), Hessen im Frühmittelalter. Archäologie und Kunst: 24-33. Sigmaringen: Thorbecke Verlag.

SHEPHARD, J. 1979. The social identity of the individual in isolated barrows and barrow cemeteries in Anglo-Saxon England, in B.C. Barnham \& J. Kingsbury (ed.), Space, hierarchy and society. Interdisciplinary studies in social area analysis: 47-79. Oxford: British Archaeological Reports. International series 59.

1980. Anglo-Saxon barrows of the later 6th and 7th centuries AD. Ph.D dissertation. University of Cambridge.

SPEAKE, G. 1989. A Saxon bed burial on Swallowcliffe Down. London: English Heritage.

STEIN, F. 1967. Adelsgräber des 8. Jahrhunderts in Deutschland. Bern: Germanische Denkmäler der Völkerwanderungszeit. Serie A, Band 9.

STEUER, H. 1989. Archaeology and history: proposals on the social structure of the Merovingian kingdom, in K. Randsborg (ed.), The birth of Europe: archaeology and social development in the first millenium $A D$ : 100-22. Rome: L'Erma di Bretschneider.

STORK, J. 1985. Abschluß der Untersuchungen des Fränkischen Friedhofs von Dittigheim, Stadt Tauberbischofsheim, Main-Tauber-Kreis, Archäologische Ausgrabungen in BadenWürttemberg 1985: 187-95.

TAINTER, J. 1978. Mortuary practices and the study of prehistoric social systems, in M. Schiffer (ed.), Advances in archaeological theory and method: 106-37. New York (NY): Academic Press.

TREUNE-GROSSKOPF, B. 1989. Ein frühmittelalterliche Kirchenbau mit 'Gründergrab' in Cognin (Savoyen)?, Archäologisch Korrespondenzblatt 19: $283-96$

VON FREEDEN, U. 1987. Das frühmittelalterliche Gräberfeld von Moos-Burgstall, Ldkr. Deggendorf in Niederbayern, Bericht der RömischGermanichen Kommission 68: 493-637.

VON FREEDEN, U. \& H.J. KÖHLER. 1981. Neue bajuwarische Adelsgräber von Moos-Burgstall, Landkreis Deggendorf, Niederbayern, Das archäologische Jahr in Bayern 1981: 166-7.

WATKIN, J. \& F. MANN. 1981. Some late Saxon finds from Lilla Howe, N. Yorks, and their context, Medieval Archaeology 25: 153-7.

WoOD, I. 1983. The Merovingian North Sea. Ålingsas: Occasional papers on Medieval topics 1.

YOUNG, B.K. 1975. Merovingian funeral sites and the evolution of Christianity: a study in the historical interpretation of archaeological evidence. Ann Arbor (MI): University Microfilms International. 